\title{
Soil Property Variation within Taxa of ST at University of Nigeria, Nsukka
}

\author{
Emeka P. Ukaegbu ${ }^{1} \&$ Frank O. R. Akamigbo ${ }^{2}$ \\ ${ }^{1}$ Dept. of Agric. Science, Alvan Ikoku Federal College of Education, Owerri, Nigeria \\ ${ }^{2}$ Dept. of Soil Science, University of Nigeria, Nsukka \\ Correspondence: Emeka P. Ukaegbu, Dept. of Agric. Science, Alvan Ikoku Federal College of Education, \\ Owerri, Nigeria.
}

Received: January 18, 2021

Accepted: February 18, 2021

Online Published: March 3, 2021

doi:10.5539/mas.v15n2p36

URL: https://doi.org/10.5539/mas.v15n2p36

\begin{abstract}
Study evaluated predictive accuracy of USDA Soil Taxonomy Classifications of Soils of University of Nigeria, Nsukka. Data from $0-20 \mathrm{~cm}$ and $30-60 \mathrm{~cm}$ depths of 9 profiles, each representing a map unit, were used to determine coefficients of variation (CV) of soil properties over whole area sampled (control), within Great group class and series. There was progressive reduction in CVs from high to low categories, with the properties doing so irregularly. Average CVs for the various levels were 59.58\% (over whole area), 56.97\% (Great group), 50.77\% (series) at topsoil, while at subsoil they were 38.15\% (whole area), 31.53\% (Great group), 25.19\% (series). At topsoil, predictions of K \& OC improved by $36.16 \%$ on the average at Great group, while it did for Clay, K, OC by $43.71 \%$ at series. At subsoil Silt, $\mathrm{Mg}, \mathrm{CEC}, \mathrm{OC}, \mathrm{TN}$ improved by $34.17 \%$ at Great group on the average, while Clay, Silt, Mg, CEC, OC, TN, av.P did by $47.49 \%$ at series. Predicted properties, which were found to correlate with others, influence soil productivity. Sand and $\mathrm{pH}$ were virtually unaffected by classification. Study highlights a technique for evaluating predictive accuracy of soil classification using small sample size as well as the essence of detailed characterization of the soils.
\end{abstract}

Keywords: accuracy, classification, Nsukka, prediction, soils, ST

\section{Introduction}

Soil classification is a scientific tool for the systematic study of soils as it organizes knowledge of soils, bringing out their relationships, thereby making possible prediction of their behavior, technical communication and technology transfer. The process entails recognition of soil classes which Rossiter, Zeng and Zhang (2017) have noted to be information carriers that present a holistic view of groups of soil individuals with definite "personality" and which they further noted, have proven useful as the units of soil survey interpretation. An array of classes (i.e. taxa, plural for taxon) at a given level of abstraction in a hierarchical system such as the United States Department of Agriculture (USDA) Soil Taxonomy (ST), represents a category. The USDA Soil Taxonomy is the main system adopted in Nigeria (Esu, 2010; Ogunkunle, 2005). It classifies soils at six levels in a hierarchical system, from highest to lowest - Order, Suborder, Greatgroup, Subgroup, Family and Series - with the Phase being an informal level superimposed at any of the other levels to capture features such as surface stoniness, slope steepness, erosion, that are important to landuse (Bockhein, Geenadiyez, Hammer, \& Tandarich, 2005; Brevik, Calzolari, Miller, Pereira, Kabala, Baumgarten, \& Jordan, 2016; Soil Survey Staff, 2014). The hierarchical levels are assumed to represent degrees of similarity (Rossiter et al., 2017). According to Butler (1980) Series is of least taxonomic difference while Greatgroup is of high taxonomic difference. Series and their Phases constitute mapping units at detailed scales of soil mapping while the higher categories (e.g. Greatgroup) are mapping units at semi-detailed and small scales of mapping (Akamigbo, 2010; Ezeaku, 2011).

Spatial characterization of soil properties is necessary to locate homogenous areas to be carefully managed for agricultural sustainable development (Ghartey, Dowuona, Nartey, Adjadeh, \& Lawson, 2012). On the other hand, Calleja-Cervantes, Fernandez-Gonzalez, Irigoyen, Fernandez-Lopez, Aparicio-Tejo and Menendez (2012) consider the identification of soil properties that control soil quality indicators as vital to plan appropriate soil management. The efficiency of different digital and conventional soil mapping approaches to produce categorical maps of soil types is determined by cost, sample size, accuracy and the selected taxonomic level (zeraatpisheh, Ayoubi, Jafari, \& Finke, 2017). However, Kempen, Brus, Stoorvogel, Heuvelink and de Vries 
(2012) note that conventional methods of soil mapping are currently considered to be ineffective to produce detailed soil maps at a reasonable cost and time. Stehman and Czaplewski (1998) hold the view that accuracy assessment quantifies data quality so that map users may evaluate the utility of a thematic map for their intended applications. Observing the assessment to begin with the definition of the target population, they recommend simple sampling design as such is easier to implement and analyze.

The act of soil classification is usually fraught with incorrect allocations. This is more so with the criticisms of ST - complexity and over reliance on laboratory analysis; focus on soils of the United States of America, particularly for earlier versions of the system (Beinroth, 1990; Butler, 1980; Young, 1976).

So, to determine the usefulness of the soil's classification as tool for soil management requires evaluation of classification accuracy. Dent and Young (1980) note that the variability of soil properties within a mapping unit (i.e. purity of unit) is the standard by which the quality of any survey is assessed. However, Rossiter et al. (2017) opine that evaluating the accuracy of allocation to classes in monothetic hierarchical soil classification system is poorly served by binomial methods (correct/incorrect allocation per evaluation observation) since some errors are more serious than others in terms of soil properties, mapuse, pedogenesis, and ease of mapping. They therefore recommend that evaluations should account for the taxonomic distance - amount of separation between classes in some feature space - between classes, expressed as class similarities, giving partial credit to some incorrect allocations. Also observing soil mapping units as delineations of polypedons, as well as the difficulty of measuring purity of mapping units by statistical inference of individual soil properties, Notohadiprawiro (2006) noted that it is more appropriate to assess the purity of units by profile types as they are expressions of polypedons. Earlier studies employing the binomial method (Akamigbo, 1986; Ameyan, 1986) in the area of study produced poor results as most properties had high CVs within the unit. Determining CVs of properties within a map unit only, as is often the case, does not show the difference in prediction between high and low categories of ST. Such a comparison incorporates the idea of taxonomic distance while enhancing interpretation of the evaluation. It further shows the essence of detailed characterization of the soils. Perhaps, due to ease of operation, use of predetermined permissible limit of CVs within soil unit to determine its purity is common with scientists in the area of study.

While detailed soil maps are generally lacking in the area of study (Achukwu, Raji, \& Lya'u, 2013; Ojuola et al., 2019), no attempt has been made to compare predictive accuracies of soil classes at different categoric levels. A detailed soil map of University of Nigeria, Nsukka (Ukaegbu \& Akamigbo, 2004) provided an opportunity for such an evaluation. So, the general objective of study was to assess the predictive accuracy of soil classification at the University of Nigeria, Nsukka using the USDA Soil Taxonomy. Specifically, study aimed at determining:

- Influence of category of soil classification on spatial variation and prediction of soil properties;

- Influence of soil depth on soil property spatial variation and prediction;

- Properties that are best predicted;

- Usefulness of classification/mapping as guide for soil management.

Study highlights a technique for evaluating soil classification and mapping accuracy using small sample size.

\section{Materials and Methods}

\subsection{Area of Study}

Nsukka is at the northern part of Enugu State of Nigeria, lying approximately by Lat. $6^{0} 52 \mathrm{~N}$ and Long. $7^{0} 23 \mathrm{E}$. The location belongs to climatic region that has four dry months, an annual total rainfall of 1,708mm, and mean temperature range of $27^{\circ} \mathrm{C}-28^{\circ} \mathrm{C}$. The vegetation is derived savanna which is dominated by hyparrhenia grass species. The location is of a cuesta landscape with relief of $350-500 \mathrm{~m}$ above sea level. Soil parent materials are False-bedded Sandstone and Upper coal measures. Landuse within the University as at the time of study were mainly Arable, Tree-crops, Grazing and Irrigation. These facts are drawn mainly from Asadu, Dion and Okechukwu (2002) and Ofomata (1975).

\subsection{Field Study}

All unbuilt-up areas (595.25ha) of University of Nigeria, Nsukka, used mainly for farming, were subjected to intense survey activities which resulted in the delineation of nine (9) map units. The units were either series or phases of series. Soil map produced was at a scale of 1:5,000. Each unit had a representative profile located at site most typical of unit. The profiles were described following FAO (1977) guidelines. Samples were taken from horizons of profiles for laboratory analyses. 


\subsection{Laboratory Analysis}

Soil samples got from the field were air-dried and sieved with a sieve of $2 \mathrm{~mm}$ mesh size. The fine-earth fraction was subjected to routine analyses using standard procedures. Particle size analysis was by the hydrometer method of Gee and Or (2002). Soil pH was determined using a glass electrode $\mathrm{pH}$ meter in a soil-to-water ratio of 1:2.5. Organic carbon was determined using oxidation method as modified by Nelson and Sommers (1990). Total Nitrogen was determined by Macro-Kjeldahl method of Black (1965). Exchangeable bases were extracted with neutral normal ammonium acetate solution. $\mathrm{Ca}^{++}$and $\mathrm{Mg}^{++}$in the extract were determined by EDTA titration, while $\mathrm{K}^{+}$and $\mathrm{Na}^{+}$were by flame photometry. Cation exchange capacity (cec) was got by the method of Jackson (1958). Base saturation was got by expressing total exchangeable bases (TEB) as a percentage of CEC.

\subsection{Soil Classification}

Using data from the field and laboratory, soils were classified by the standards of USDA Soil Taxonomy (Soil Survey Staff, 1975) and FAO/Unesco Soil Legend (1987). Soil units identified by detailed mapping of soils of University of Nigeria, Nsukka (Ukaegbu \& Akamigbo, 2004) are shown in Table 1.

Table 1. Soil classification at University of Nigeria, Nsukka

\begin{tabular}{llll}
\hline Profile Number & Soil Taxonomy & FAO & Series Name \\
\hline 1 & Typic Paleustult & Ferric Acrisol & Nkpologu \\
2 & Typic Paleustult & Ferric Acrisol & Nkpologu \\
3 & Typic Paleustult & Ferric Acrisol & Nsukka \\
4 & Arenic Paleustult & Ferric Acrisol & Nsukka \\
5 & Typic Paleustult & Ferric Acrisol & Nkpologu \\
6 & Petroferric Haplustox & Plinthic Ferralsol & Uvuru \\
7 & Typic Paleustult & Ferric Acrisol & Nkpologu \\
8 & Typic Paleustult & Ferric Acrisol & Nkpologu \\
9 & Typic Paleustult & Ferric Acrisol & Nkpologu
\end{tabular}

By the standards of ST, classes of soils identified as indicated by Table 1, were Typic Paleustult, Arenic Paleustult, Petroferric Haplustox. Low silt/clay and silt/silt+clay ratios, argillic horizons, low CEC and dominance of kaolinite indicating advanced stage of weathering informed soils' classifications. Stoniness of soil of profile 6 and its position on the crest of hills were considered in classifying it as Petroferric Hapluslox. For the FAO equivalents, profile 6 was classified as Plinthic Ferralsols while the rest were classified as Ferric Acrisol. The soils were further resolved into Nkpologu Series, Nsukka Series and Uvuru Series (Table 1). Percentages of total area occupied by each of the series were $26.9 \%, 66.6 \%, 6.6 \%$ for Uvuru, Nkpologu and Nsukka, respectively (Ukaegbu \& Akamigbo, 2004). Nkpologu occupied the largest land area while Nsukka the least.

\subsection{Statistical Analyses}

Data taken from $0-20 \mathrm{~cm}$ (A-horizon) and $30-60 \mathrm{~cm}$ (B-horizon) depths of profiles were used for statistical analyses. Variability of soil properties was expressed in terms of coefficient of variation (CV) determined by expressing standard deviation as a percentage of mean. The variability of properties was determined over the whole area mapped, within Paleustult class at Greatgroup level and within Nkpologu series for comparison. Variation of properties over the whole area (prior to classification) served as control. If classification was to stop at Greatgroup level only two classes (by ST) namely Paleustult (8 profiles) and Haplustox (1 profile) would have been recognized. So, only data from eight (8) profiles were used at this stage. At the third stage (series), only data from Nkpologu (6 profiles) were used. The CVs were rated on the basis of the scale of Wilding, Bouma and Boss (1994): CV(\%) $\leq 15 \%$, low; CV $(\%)>15$ to $\leq 35 \%$, moderate; CV $>35 \%$, high. Pearson's Product Moment Correlation Model was used to correlate properties, at 0.01 and 0.05 levels of significance.

\section{Results}

Differences in the soils manifested in high variability of their properties. Variations of topsoil properties at the different levels are given in Table 2. 
Table 2. Variations of Topsoil properties within taxa of different categories given as CV (\%)

\begin{tabular}{llll}
\hline Soil Property & Whole Area & Greatgroup & Series \\
\hline Clay & 52.01 & 56.35 & $\mathbf{3 2 . 3 7}$ \\
Silt & 61.08 & 65.57 & 58.99 \\
Sand & 21.24 & 21.41 & 18.72 \\
$\mathrm{pH}$ & 5.14 & 4.99 & 4.84 \\
$\mathrm{Ca}$ & 87.80 & 89.09 & 74.08 \\
$\mathrm{Mg}$ & 78.26 & 85.07 & 72.85 \\
$\mathrm{~K}$ & 81.16 & $\mathbf{4 0 . 6 0}$ & $\mathbf{4 0 . 3 6}$ \\
$\mathrm{Na}$ & 91.19 & 99.64 & 107.44 \\
$\mathrm{CEC}$ & 52.12 & 52.12 & 45.59 \\
$\mathrm{BS}$ & 39.90 & 41.71 & 41.66 \\
OC & 73.76 & $\mathbf{5 6 . 6 2}$ & $\mathbf{4 1 . 9 8}$ \\
$\mathrm{TN}$ & 54.61 & 50.56 & 47.43 \\
Av.P & 76.27 & 76.84 & 73.75 \\
Ave. CV $(\%)$ & 59.58 & 56.97 & 50.77 \\
\hline
\end{tabular}

Over the whole area (i.e. prior to classification) $\mathrm{CVs}$ of properties as shown by table 2 ranged from $5.14 \%$ for $\mathrm{pH}$ to $91.19 \%$ for $\mathrm{Na}$. So, by the rating scale of Wilding et al. (1994), pH had low variation over the whole area, while sand had moderate variation. The rest of the properties had high variation.

At Greatgroup level CVs of properties ranged from $4.99 \%$ for $\mathrm{pH}$ to $99.64 \%$ for $\mathrm{Na}$. $\mathrm{P}^{\mathrm{H}}$ had low variation, sand moderate variation and the rest varied highly. Only the variations of $\mathrm{K}$ and OC reduced somewhat significantly at Greatgroup level. K reduced by $49.98 \%$ while OC reduced by $23.24 \%$.

At Series, CVs ranged from $4.84 \%$ for $\mathrm{pH}$ to $107.44 \%$ for $\mathrm{Na} . \mathrm{P}^{\mathrm{H}}$ had low variation, Sand and Clay moderate variation, while the rest varied highly. Properties whose CVs reduced significantly (relatively) at this level are Clay, K and OC. They reduced by $37.76 \%, 50.27 \%$ and $43.09 \%$ respectively. Average CVs for the categoric levels are $59.58 \%$ (prior to classification), 56.97\% at Greatgroup level and $50.77 \%$ at Series. So, there is a progressive decrease from higher category to the lower. But the properties have done so irregularly.

Variations of subsoil properties at the different categories are given in Table 3.

Table 3. Variations of subsoil properties within taxa of different categories given as CV (\%)

\begin{tabular}{llll}
\hline Soil Property & Whole Area & Greatgroup & Series \\
\hline Clay & 50.68 & 54.64 & $\mathbf{3 4 . 7 0}$ \\
Silt & 42.32 & $\mathbf{3 5 . 4 6}$ & $\mathbf{2 7 . 5 7}$ \\
Sand & 28.45 & 27.64 & 23.42 \\
$\mathrm{pH}$ & 3.27 & 3.23 & 3.73 \\
$\mathrm{Ca}$ & 28.01 & 38.66 & 32.35 \\
$\mathrm{Mg}$ & 104.20 & $\mathbf{5 8 . 2 7}$ & $\mathbf{4 8 . 5 6}$ \\
$\mathrm{K}$ & 27.90 & 29.16 & 33.34 \\
$\mathrm{Na}$ & 32.30 & 34.65 & 37.02 \\
$\mathrm{CEC}$ & 45.46 & $\mathbf{2 6 . 0 0}$ & $\mathbf{2 0 . 5 0}$ \\
$\mathrm{BS}$ & 13.61 & 14.27 & 15.51 \\
OC & 53.08 & $\mathbf{3 2 . 6 2}$ & $\mathbf{1 0 . 7 7}$ \\
$\mathrm{TN}$ & 37.36 & $\mathbf{2 6 . 4 5}$ & $\mathbf{1 9 . 6 4}$ \\
Av.P & 29.30 & 28.88 & $\mathbf{2 0 . 3 4}$ \\
Ave. CV (\%) & 38.15 & 31.53 & 25.19
\end{tabular}

Over the whole area, properties' $\mathrm{CVs}$ ranged from $3.27 \%$ for $\mathrm{pH}$ to $104.20 \%$ for $\mathrm{Mg}$. $\mathrm{P}^{\mathrm{H}}$ and $\mathrm{BS}$ had low variation; Sand, $\mathrm{Ca}, \mathrm{K}, \mathrm{Na}$, av.P had moderate variation, while the rest varied highly. At Greatgroup level CVs have ranged from $3.23 \%$ for $\mathrm{pH}$ to $58.27 \%$ for $\mathrm{Mg}$. $\mathrm{P}^{\mathrm{H}}$, BS had low variation; Sand, $\mathrm{K}, \mathrm{Na}, \mathrm{CEC}, \mathrm{OC}$, TN, av.P had moderate variation while Clay, Silt, $\mathrm{Ca}, \mathrm{Mg}$ varied highly. Properties whose CVs reduced significantly (at least in relative terms) at this level were Silt, $\mathrm{Mg}, \mathrm{CEC}, \mathrm{OC}, \mathrm{TN}$ and these were by $16.21 \%, 44.08 \%, 42.81 \%$, $38.55 \%, 29.2 \%$ respectively. At series level, CVs of properties ranged from $3.73 \%$ for $\mathrm{pH}$ to $48.56 \%$ for $\mathrm{Mg}$. $\mathrm{P}^{\mathrm{H}}$ 
and OC had low variation; Clay, Silt, Sand, Ca, K, CEC, BS, TN, av.P moderate variation while Mg and $\mathrm{Na}$ varied highly. Properties whose CVs reduced significantly at this level were Clay, Silt, Mg, CEC, OC, TN, av.P and these were by $31.53 \%, 34.85 \%, 53.4 \%, 54.91 \% 79.71 \%, 47.43 \%, 30.58 \%$ respectively. Average CVs for the categories at subsoil were $38.15 \%$ (prior to classification), $31.53 \%$ at Greatgroup and $25.19 \%$ at series. There is also progressive decrease from high to low categories at the subsoil.

Prediction can thus be said to improve by the same proportion that variation has reduced across categories.

Parameters whose predictions improved at lower category have correlated with others. Often the number of parameters predicted is taken as measure of efficiency. But their effect could be more due to Correlation with other properties.

Table 4. Relationships among topsoil properties given in terms of Correlation Coefficients (r)

\begin{tabular}{|c|c|c|c|c|c|c|c|c|c|c|c|c|c|}
\hline & Sand & Silt & Clay & pH & $\mathbf{C a}$ & Mg & $\mathbf{K}$ & $\mathbf{N a}$ & CEC & $\mathbf{B S}$ & $\mathbf{O C}$ & $\mathbf{T N}$ & av.P \\
\hline Sand & 1 & & & & & & & & & & & & \\
\hline Silt & $-.902 * *$ & 1 & & & & & & & & & & & \\
\hline Clay & $-.990 * *$ & $.833 * *$ & 1 & & & & & & & & & & \\
\hline $\mathrm{pH}$ & .436 & -.394 & -.432 & 1 & & & & & & & & & \\
\hline $\mathrm{Ca}$ & $-.721 *$ & $.702 *$ & $.698 *$ & -.173 & 1 & & & & & & & & \\
\hline $\mathrm{Mg}$ & -.399 & .265 & .425 & -.268 & $.680^{*}$ & 1 & & & & & & & \\
\hline $\mathrm{K}$ & -.491 & .594 & .438 & .252 & $.785^{*}$ & .154 & 1 & & & & & & \\
\hline $\mathrm{Na}$ & -.554 & $.779 *$ & .459 & -.193 & $.796^{*}$ & .394 & $.712^{*}$ & 1 & & & & & \\
\hline CEC & $-.797 *$ & $.879 * *$ & $.738^{*}$ & -.326 & $.861 * *$ & .526 & $.707^{*}$ & $.833 * *$ & 1 & & & & \\
\hline $\mathrm{BS}$ & -.453 & .394 & .453 & .050 & $.797 *$ & $.736^{*}$ & .488 & .610 & .476 & 1 & & & \\
\hline $\mathrm{OC}$ & $-.878 * *$ & $.870 * *$ & $.844 * *$ & -.231 & $.913 * *$ & .429 & $.822 * *$ & $.749 *$ & $.920 * *$ & .554 & 1 & & \\
\hline $\mathrm{TN}$ & $-.930 * *$ & $.948 * *$ & $.886^{* *}$ & -.403 & $.833^{* *}$ & .360 & $.699 *$ & $.756^{*}$ & $.900 * *$ & .479 & $.963 * *$ & 1 & \\
\hline av.P & .391 & -.275 & -.412 & -.391 & -.056 & -.027 & -.169 & .097 & -.226 & .005 & -.249 & -.188 & 1 \\
\hline
\end{tabular}

**Correlation is significant at the 0.01 level (2-tailed)

*Correlation is significant at the 0.05 level (2-tailed)

Table 4 shows relationships among topsoil properties. Among these, the well predicted properties - Clay, K, OC - had significant relationships with others. Clay correlated with Sand, Silt, Ca, CEC, OC, TN. Exchangeable-K correlated with $\mathrm{Ca}, \mathrm{Na}, \mathrm{CEC}, \mathrm{OC}, \mathrm{TN}$. Organic Carbon (OC) correlated with Sand, Silt, Clay, Ca, K, Na, CEC, TN.

Table 5. Relationships among subsoil properties given in terms of Correlation Coefficients (r)

\begin{tabular}{|c|c|c|c|c|c|c|c|c|c|c|c|c|c|}
\hline & Sand & Silt & Clay & pH & $\mathbf{C a}$ & Mg & $\mathbf{K}$ & $\mathbf{N a}$ & CEC & BS & $\mathrm{OC}$ & TN & av.P \\
\hline Sand & 1 & & & & & & & & & & & & \\
\hline Silt & -.662 & 1 & & & & & & & & & & & \\
\hline Clay & $-.994 * *$ & .576 & 1 & & & & & & & & & & \\
\hline $\mathrm{pH}$ & .388 & .078 & -.434 & 1 & & & & & & & & & \\
\hline $\mathrm{Ca}$ & $-.878 * *$ & $.697^{*}$ & $.856^{* *}$ & -.386 & 1 & & & & & & & & \\
\hline $\mathrm{Mg}$ & -.610 & $.834 * *$ & .544 & .114 & .516 & 1 & & & & & & & \\
\hline $\mathrm{K}$ & -.259 & .359 & .230 & -.350 & .359 & .442 & 1 & & & & & & \\
\hline $\mathrm{Na}$ & -.603 & .165 & .633 & -.481 & .332 & .268 & .354 & 1 & & & & & \\
\hline CEC & $-.716^{*}$ & $.886^{* *}$ & .653 & .091 & .645 & $.981 * *$ & .427 & .281 & 1 & & & & \\
\hline BS & $-.732 * *$ & .556 & $.717^{*}$ & $-.668 *$ & $.772 *$ & .549 & .544 & .598 & .574 & 1 & & & \\
\hline $\mathrm{OC}$ & -.658 & $.828 * *$ & .597 & .174 & .522 & $.943 * *$ & .160 & .213 & $.942 * *$ & .473 & 1 & & \\
\hline $\mathrm{TN}$ & $-.736^{*}$ & $.789 *$ & $.688^{*}$ & -.091 & .531 & $.910 * *$ & .308 & .349 & $.912 * *$ & .551 & $.921 * *$ & 1 & \\
\hline av.P & .593 & -.359 & -.595 & -.011 & -.305 & -.471 & -.096 & -.487 & -.503 & -.219 & -.590 & -.593 & 1 \\
\hline
\end{tabular}

**Correlation is significant at the 0.01 level (2-tailed)

*Correlation is significant at the 0.05 level (2-tailed)

At the Subsoil (Table 5) the well predicted properties also correlated significantly with others. Clay correlated with Sand, Ca, BS, TN. Silt correlated with $\mathrm{Ca}, \mathrm{Mg}, \mathrm{CEC}, \mathrm{OC}, \mathrm{TN}$. Exchangeable-Mg correlated with Silt, CEC, 
OC, TN. Cation exchange capacity (CEC) correlated with Sand, Silt, Mg, OC, TN. Organic Carbon (OC) correlated with Silt, Mg, CEC, TN. Total nitrogen (TN) correlated with Sand, Silt, Clay, Mg, CEC, OC. Available-P (av.P) was not correlated with any other property.

\section{Discussion}

Earlier studies had found comparable relationships among properties of soils of location of study. Unamba-Oparah (1985) found k-bearing minerals to be tied up with fine Sand and Silt components of sandy soils of northern Imo State, Nigeria. Asadu and Akamigbo (1990) found CEC of soils of southeastern Nigeria to relate significantly with OC and Clay. Asadu and Enete (1997) found that in most zones of sub-Saharan African ECEC correlated significantly with Clay, Silt, OM, with the later (OM) contributing as much as $60 \%$ of ECEC.

While difference in area covered by each of the classes at different categories might have influenced result, particularly for the spatially dependent properties, the differences in origin of soils might also have influenced the variation in properties. According to Asadu (1990), soils of Nsukka have generally been derived from the residua of either Falsebedded sandstone or Upper coal measure formations. The Uppercoal measures occupy the upper slopes and tops of residual hills, he further explained. Akamigbo and Igwe (1990) noted Uvuru series to have derived from weathered uppercoal measures, while Nkpologu and Nsukka series were derived from wathered false-bedded sand-stones and colluviums from the weathered uppercoal measures. Explaining further they noted Uvuru, Nsukka and Nkpologu to occur in a catenary association. Nkpologu may follow Uvuru, but where Uvuru is absent Nsukka and Nkpologu then form a first order catena. Elevation and aspect of ridges/hill seem to influence the positions of the series according to the same authors. Uvuru is very gravelly, sandyloam and sandyclay loam/very gravelly clay or sandy clay, having higher organic matter content than either of the other series. Nsukka and Nkpologu are very deep, dark reddish brown to reddish brown in the epipedon and red in subsoils, coarse to medium textured, with Nsukka being coarser particularly at the subsoil.

Management is also believed to have contributed to the high variability of properties at the topsoil. Asadu and Bosah (2003) found land utilization types in the location of study to constitute a major factor in the variation of soil properties-Sand, Clay, pH, K, Ca, CEC, BS. Such influence is less at the subsoil hence the improved prediction there. Improvement in prediction at subsoil is also as a result of subsoil properties being used as differentiae for the various classes. The great variation of properties, particularly at the topsoil, had been recorded in earlier studies hence Akamigbo (1986) and Ameyan (1986) recommended a CV of 33\% as upper limit of homogeneity for 'series' in the area. But only a few parameters (clay, sand, $\mathrm{pH}$ ) met this standard at the topsoil in present study. Butler (1980) attributes such poor prediction to unco-ordinated variations in soil data pool, misplacement of taxonomic chops and/or error created by act of mapping. However, prediction at topsoil will improve if evaluation is at phase level. The phases are defined mostly by slope and, Akamigbo and Asadu (1986) had found topography to influence depth of solum, particle size, OC content, CEC, TEB and Exch. Acidity in the area. Similarly, Adhikari, Owens, Ashworth, Sauer, Libohova, Richter and Miller (2018) reported slope, landscape position, variations in microtopography to be among factors that influence spatial distribution of soil nutrients. But relief is not used in defining taxa in soil Taxonomy (Bockheim, Geenadiyez, Hartemink, \& Brevik, 2014), so capturing the effect of relief has to be at phase level. The subsoil prediction can also guide management to some extent. Ngwu et al. (2005) found surface soil removal in location of study to have more severe effect on Nsukka Series than Nkpologu Series due to the differences in their fertility potentials.

The progressive decrease of CVs from higher to lower categories is in agreement with the levels varying in taxonomic difference (Butler, 1980). Sand and $\mathrm{pH}$ have not been influenced by classification at any level. Asadu (1990) attributed the low variability of $\mathrm{pH}$ of the soils to inherent acidic nature of the soils resulting from the influence of parent material and climate. It is also on record that the soils are dominated by the sand fraction of their particle sizes. However, well predicted parameters have influence on soil productivity. Sand, Silt, $\mathrm{Clay,} \mathrm{pH}$, $\mathrm{Mn}, \mathrm{Mg}, \mathrm{Ca}, \mathrm{ECEC}, \mathrm{BS}, \mathrm{N}, \mathrm{P}, \mathrm{K}$ have variously been found to influence soil productivity in the area of study (Asadu \& Enete, 1997; Asadu \& Akamigbo, 1990; Nottidge, Ojeniyi, \& Asawalam, 2007).

The purpose of the delineation of the mapping units on soil maps is to enable user to predict soil properties of the individual mapping units more precisely than those of the area as a whole. Without comparison with values at higher levels, the conclusion will be that there is poor prediction (i.e. high impurity) at series level. But it can be seen that some parameters (Sand, pH) with low CV at series also had low CV at higher category. So, low CV at series may not necessarily imply improvement in prediction. On the other hand, $\mathrm{K}$ and OC with high CV at series improved significantly coming from the higher categories. Determining CVs of parameters at Series only does not reflect the difference in prediction between high and low categories.

Study highlights the essence of detailed characterization of soils. The University of Nigeria, Nsukka is one of a few areas where soils have been characterized in detail in Southeast Nigeria. Only reconnaissance Soil Maps cover the whole area that is Nigeria (Ojuola, Asawalam, Jibrin, Oshadia, \& Noma, 2019). Malgwi and Raji 
(2005) report that only $0.58 \%$ (567.421 ha) of Nigeria is covered by detailed soil survey. Expounding this, Achukwu et al. (2013) noted that soil survey to the series level has been well documented in Southwest Nigeria but not so for the other zones of the country. They then concluded that lack of knowledge about soil resources and how to manage them is a primary constraint to sustainable and successful agricultural programme. Minasny, McBratney and Hartemink. (2010) also observed that areas with more detailed soil mapping units exhibit the largest pedodiversity. They then concluded that the measure of pedodiversity depends, amongst others, on the detail of the soil survey in an area. So, there is the need to do more detailed soil surveys in Southeast Nigeria so as to identify more soil series. This is necessitated by the pressure on the land due to high population density in the area.

So, comparing variations of soil properties within a series with those of a class at higher category (e.g. Greatgroup) facilitates interpretation of evaluation results as it shows the progress made between the high and low category. In such studies, the series should be compared with its related class at Greatgroup level. For example, each of Nkpologu and Nsukka should be related to Paleustult, while Uvuru should be related to Haplustox. All classes at same category are assumed taxonomically equidistant to their related classes at the higher category. Such relationships of classes at same category with their related classes at higher category also makes possible lateral evaluations and comparisons of classes at same categoric level. To compare classes at same category (e.g. Nsukka vs Nkpologu) areas sampled from should be equal. This was not done in this study due to insufficient data. As soil properties and classifications can change within decadal time scales (Busch \& Presley, 2014; Veenstra \& Burras, 2012) it is necessary to update the soils classifications.

This is a technique for evaluating predictive accuracy of soil classification by ST using small sample size. Result got can as well serve as indicating mapping accuracy since profiles were sited at locations most typical of soil class. Yang et al. (2016) noted that one effective way to capture the greatest soil variability is by sampling at those locations where the soils are most typical of the class. The results of this study will be standard for comparisons of subsequent characterization and classification of the soils.

\section{Conclusion}

Despite high variability of properties within Nkpologu Series, there is significant reduction in variation, and thus improvement in prediction, mainly at the subsoil for properties - Clay, Silt, Mg, CEC, OC, TN, av.P - compared with values at high category. Comparison of variations of properties at Series and Greatgroup levels enhances interpretation of evaluation of purity of units at Series when such is based on use of predetermined permissible limits of coefficient of variation. Study highlights technique for evaluating predictive accuracy of soil classification using small sample size, as well as the essence of detailed characterization of soils of the location. However, the evaluation should involve all soil units and soils' classifications should be updated.

\section{References}

Achukwu, E. M., Raji, B. A., \& Lya'u, S. (2013). Compilation of existing soil series in northeastern Nigeria: Problem and prospect. Nigerian Journal of Soil Science, 23(2), 189-195.

Adhikari, K., Owens, P. R., Ashworth, A. J., Sauer, T. J., Libohova, Z., Richter, J. L., \& Miller, D. M. (2018). Topographic controls on soil nutrient variations in a silvopasture system. Agrosystems, Geosciences \& Environment, 1(1), 1-15. https://doi.org/10.2134/age2018.04.0008

Akamigbo, F. O. R., \& Asadu, C. L. A. (1986). The influence of topograpy on some soil parameters in selected areas of Anambra State, Nigeria. Niger. J. Soil Sci., 6, 35-46.

Akamigbo, F. O. R. (1986). Soil variability within map units in areas of low and undulating relief: A case study on Abakaliki/Okigwe anticlinorium, Eastern Nigeria. The Nigerian Agric. Journal, 21, 81-89.

Akamigbo, F. O. R. (2010). Soils: Fundamental methods of soil resource survey, classification, interpretation and application. Nsukka: Univ. of Nigeria Press Ltd.

Akamigbo, F. O. R., \& Igwe, C. A. (1990). Morphology, geography, genesis and taxonomy of three soil series in eastern Nigeria. Samaru Journal of Agricultural Research, 7, 33-48.

Ameyan, O. (1986). Surface soil variability of map unit on Niger river alluvium. Soil Sci. Soc. Am. J., 50, 1289-1293. https://doi.org/10.2136/sssaj1986.03615995005000050041x

Asadu, C. L. A., \& Akamigbo, F. O. R. (1990). Relative contributions of organic matter and clay fractions to cation exchange capacity of soils in Southeastern Nigeria. Samaru J. Agric. Res., 7, 17-23.

Asadu, C. L. A., \& Bosah, C. S. (2003). A comparative study of the soils of the Upper Coal-Measure residua under cropped-grass-forest land continuum in Eastern Nigeria. E. Afr. Agric. For. J., 68(4), 205-212. https://doi.org/10.4314/eaafj.v68i4.1798 
Asadu, C. L. A., \& Enete, A. A. (1997). Food crop yields and soil properties under population pressure in subsaharan African: the case of cassava in southeast Nigeria. Outlook on Agriculture, 26(1), 29-34. https://doi.org/10.1177/003072709702600107

Asadu, C. L. A. (1990). A comparative characterization of two foot-slope soils in the Nsukka area of Eastern Nigeria. Soil Science, 150(2), 527-534. https://doi.org/10.1097/00010694-199008000-00006

Asadu, C. L. A., Akamigbo, F. O. R., Ezumah, H. C., \& Nweke, F. (1990). The characterization of selected Yam-Growing Soils in Southeastern Nigeria. I. Physical and Morphological Properties. Nigerian Agricultural Journal, 24, 55-69.

Asadu, C. L. A., Diels, T., \& Vanlauwe, B. (1997). A Comparison of the contributions of clay, silt, and organic matter to the effective cec of soils of subsaharan Africa. Soil Science, 163(11), 785-794. https://doi.org/10.1097/00010694-199711000-00003

Asadu, C. L. A., Dixon, A. G. O., \& Okechukwu, R. (2002). Comparative evaluation of the contributions of soil physicochemical properties to variations in the yields of four major staple food crops in eastern Nigeria. Soil \& Tillage Research, 65, 141-155. https://doi.org/10.1016/S0167-1987(01)00276-8

Beinroth, F. H. (1990). Estimating missing soil data: How to cope with an incomplete data base. Agrotechnology Transfer, 11, 10-11.

Black, C. A. (1965). Methods of Soil Analysis. Agronomy No 9, Amer. Soc. of Agron. Madison, Wisconsin. https://doi.org/10.2134/agronmonogr9.1

Bockheim, J. G., Geenadiyez, A. N., Hartemink, A. E., \& Brevik, E. C. (2014). Soil-forming factors and Soil Taxonomy. Geoderma, 226-227, 231-237. https://doi.org/10.1016/j.geoderma.2014.02.016

Bockheim, J. G., Gennadiyez, A. N., Hammer, R. D., \& Tandarich, J. P. (2005). Historical development of key concepts in Pedology. Geoderma, 124, 23-36. https://doi.org/10.1016/j.geoderma.2004.03.004

Brevik, E. C., Calzolari, C., Miller, B. A., Pereira, P., Kabala, C., Baumgarten, A., \& Jordan, A. (2016). Soil mapping, classification, and pedologic modelling: History and future directions. Geoderma, 264, 256-274. https://doi.org/10.1016/j.geoderma.2015.05.017

Busch, M. R., \& Presley, D. R. (2014). Cedar afforestation of Prairie alters soil properties on a decadal time scale. Soil Horiz, 55, 1-11. https://doi.org/10.2136/sh13-05-0015

Butler, B. E. (1980). Soil classification for soil survey. New York: Oxford University Press.

Calleja-Cervantes, M. E., Fernandez-Gonzalez, A. J., Irigoyen, I., Fernandez-Lopez, M., Aparicio-Tejo, P. M., \& Menendez, S. (2015). Thirteen years of continued application of composted organic wastes in a vineyard modify soil quality characteristics. Soil Biology and Biochemistry, 90, 241-254. https://doi.org/10.1016/j.soilbio.2015.07.002

Dent, D., \& Young, A. (1981). Soil survey and land evaluation. London: George Allen, Unwin (Pub.) Ltd.

Esu, I. E. (2010). Soil characterization, classification and survey. Ibadan: HEBEN Publishers Plc.

Ezeaku, P. I. (2011). Methodologies for agricultural landuse planning. Nsukka: Great AP Express Pub. Ltd.

FAO. (1977). Guidelines for soil profile description (2nd ed.). FAO, Rome.

FAO. (1987). FAO/Unesco soil map of the world (1:5,000,000) - Revised legend. World Soil Resources Report 60.

Gee, \& Or. (2002). Particle analysis by hydrometer method. Agronomy Journal, 43, 434-438.

Ghartey, E. O., Dowuona, G. N. N., Nartey, E. K., Adjadeh, T. A., \& Lswson, I. Y. D. (2012). Assessment of variability in the quality of an acrisol under different landuse systems in Ghana. Open Journal of Soil Science, 2, 33-43. https://doi.org/10.4236/ojss.2012.21006

Jackson, M. L. (1958). Soil Chemical Analysis Practices. England, Hall Inc.

Kempen, B., Brus, D. J., Stoorvogel, J. J., Heuvelink, G., \& de Vries, F. (2012). Efficiency comparison of conventional and digital soil mapping for updating soil maps. Soil science society of America Journal, 76(6), 2097-2115. https://doi.org/10.2136/sssaj2011.0424

Malgwi, W. B., \& Raji, B. A. (2005). Report on soil survey index map of Nigeria. National Special Programme for Food Security (NSPFS). Federal Ministry of Agriculture and Rural Development 18.

Minasny, B., McBratney, A. B., \& Hartemink, A. E. (2010). Global pedodiversity, taxonomic distance, and the World Reference Base. Geoderma, 153, 132-139. https://doi.org/10.1016/j.geoderma.2009.04.024 
Nelson, D. W., \& Sommers, I. E. (1990). Total carbon, organic carbon and organic matter. In Miller, R. H. \& Keeney, D. R. (Eds.), Methods of Soil Analysis (pp. 1085-1121). Chemical Method, ASA and SSSA. Madison, 39, 1085-1121.

Ngwu, O. E., Mbagwu, J. S. C., \& Obi, M. E. (2005). Effects of surface soil loss in south eastern Nigeria: I. Crop performance. Nigeria Journal of Soil Research, 6, 1-8. https://doi.org/10.4314/njser.v6i1.28383

Notohadiprawiro, T. (1992). Quality control of soil survey. Prosiding Pertemuan Teknis Pembakuan Sistem Klasifikasi dan Metode Survei Tanah, Tanah, Bogor, 29-31, August 1992.

Nottidge, D. O., Ojeniyi, S. O., \& Asawalam, D. O. (2007). Effect of different levels of wood ash on nutrient contents of maize (zea mays L.) and grain yield in an acid ultisol of Southeast Nigeria. Nigerian Journal of Soil Science, 17, 98-103.

Ofomata, G. E. K. (Ed). (1975). Nigeria in maps: Eastern state. Benin City: Ethiope Pub. House.

Ogunkunle, A. O. (2005). Soil survey and sustainable land management. In Salako, F. K., Adetunji, M. T., Ojanuga, A. G., Arowoilo, T. A., \& Ojeniyi, S. O. (Eds.), Managing soil resources for food security and sustainable environment. Proc. $29^{\text {th }}$ Ann. Conf. SSSN, held 6-10 Dec. 2004, Univ. of Agric., Abeokuta, Nigeria.

Ojuola, B. O., Asawalam, D. O., Jibrin, M. J., Oshadia, P., \& Noma, S. S. (2019). Strategic partnership with national and global institutions in sustainable soil productivity studies. In Raji, B. A., Asawalam, D. O. \& Adediran, J. A. (Eds.), Fifty (50) Years of Soil Science Society of Nigeria, 1969-2019 (p. 154). 1st Edition, Abuja, SSSN.

Rossiter, D. G., Zeng, R., \& Zhang, G. (2017). Accounting for taxonomic distance in accuracy assessment of soil class predictions. Geoderma, 292, 118-127. https://doi.org/10.1016/j.geoderma.2017.01.012

Soil Survey Staff. (1975). Soil taxonomy: A basic system of soil classification for making and interpreting soil surveys. Handbook No. 43. US Government Printing Office, Washington D.C., USA.

Soil Survey Staff. (2014). Keys to soil taxonomy. (12th ed.). US Government Printing Office, Washington, DC.

Stehman, S. V., \& Czaplewski, R. L. (1998). Design and analysis for thematic map accuracy assessment: Fundamental principles. REMOTE SENS. ENVIRON, https://doi.org/10.1016/S0034-4257(98)00010-8

Ukaegbu, E. P., \& Akamigbo, F. O. R. (2004). Detailed soil survey of university of Nigeria, Nsukka. In Land Degradation, Agricultural Productivity and Rural Poverty: Environment Implications. Proc. $28^{\text {th }}$ Ann. Conf. SSSN, held 4-7 Nov. 2003, at NRCRI Umudike, Abia State.

Unamba-Oparah, I. (1985). The potassium status of the sandy soils of northern Imo State, Nigeria. Soil Science, 139(5), 437-445. https://doi.org/10.1097/00010694-198505000-00009

Veenstra, J. J., \& Burras, C. L. (2012). Effects of agriculture on the classification of black soils in the Midwestern United States. Can. J. Soil Sci., 92, 403-411. https://doi.org/10.4141/cjss2010-018

Wilding, L. P., Bouma, J., \& Boss, D. W. (1994). Impact of spatial variability on interpretative modeling. In Bryant, R. B., \& Arnold, R. W. (Eds.), Quantitative modeling of soil forming process. SSSA special publ. No 39:6175.

Yang, L., Qi, F., Zhu, A., Shi, J., \& An, Y. (2016). Evaluation of integrative hierarchical stepwise sampling for digital soil mapping. Soil Science Society of America Journal, 80(3), 637-651 https://doi.org/10.2136/sssaj2015.08.0285

Young, A. (1976). Tropical soil and soil survey. Cambridge: Cambridge Univ. Press.

Zeraatpisheh, M., Ayoubi, S., Jafari, A., \& Finke, P. (2017). Comparing the efficiency of digital and conventional soil mapping to predict soil types in a semi-arid region in Iran. Geomorphology, 285, 186-204. https://doi.org/10.1016/j.geomorph.2017.02.015

\section{Copyrights}

Copyright for this article is retained by the author(s), with first publication rights granted to the journal.

This is an open-access article distributed under the terms and conditions of the Creative Commons Attribution license (http://creativecommons.org/licenses/by/4.0/). 